\title{
MANAJEMEN RISIKO TRANSAKSI DAN PENCAIRAN TRAVELLER'S CHEQUE GUNA PENCEGAHAN TINDAK PIDANA DIBIDANG PERBANKAN
}

\author{
Hassanain Haykal \\ Fakultas Hukum Universitas Kristen Maranatha Bandung, Jl. Prof. Drg. Suria Sumantri, MPH No. 65 \\ Bandung 40154, Telp. (022) 2012186 ext. 970, Hp: 08122371684, E-mail: \\ hassanain.haykal@gmail.com. \\ Johannes Ibrahim \\ Fakultas Hukum Universitas Kristen Maranatha Bandung, Jl. Prof. Drg. Suria Sumantri, MPH No. 65 \\ Bandung 40154, Telp. (022) 2012186 ext. 970, Hp: 08122142067, E-mail: \\ johannesibrahimrocketmail.com.
}

\begin{abstract}
ABSTRAK
Bank dalam menjalankan segala aktivitasnya terikat pada berbagai ketentuan perbankan, termasuk di antaranya prinsip-prinsip dan asas-asas mendasar dalam hukum perbankan. Dalam menjalankan kegiatan operasionalnya, bank akan senantiasa berhadapan dengan risiko sehingga sistem manajemen risiko dan penerapan prinsip kehati-hatian perlu diterapkan secara konsisten. Saat ini, perkembangan produk dan jasa perbankan berkembang dengan cepat. Dalam lalu lintas pembayaran, pada saat ini dikenal berbagai alat bayar yang diterbitkan oleh bank, termasuk Travel Cek. Fleksibilitas Travel Cek mengakibatkan Travel Cek mudah disalahgunakan dan dimanfaatkan sebagai sarana melakukan transaksi ilegal. Travel Cek biasanya disalahgunakan sebagai sarana melakukan beberapa tindakan kriminal diantaranya pemberian suap, penerimaan gratifikasi, dan sebagai sarana pencucian uang.
\end{abstract}

Kata Kunci : Manajemen Risiko, Traveller's Cheque, Perbankan.

\begin{abstract}
Bank in carrying out all its activities tied to various banking regulations, including the principles and fundamental principles in banking law. In conducting its operations, the bank will continue to deal with the risk that risk management systems and the application of the precautionary principle should be applied consistently. At now, the development of banking products and services is growing rapidly. In payment traffic, the currently known range of payment instrument issued by a bank, including the Travel Cheque. Flexibility of Travel Checks lead easily abused and used as a means of conducting illegal transactions. Travel Checks are commonly abused as a means of conducting a criminal act such as bribery, graft acceptance, and as a means of laundering money.
\end{abstract}

Keywords : Risk Management, Traveller's Cheque, Banking.

Copyright @ 2016, LITIGASI, p-ISSN: 0853-7100; e-ISSN: 2442-2274 
Available online at: http://ejournal.unpas.ac.id/index.php/litigasi

Litigasi, Vol. 17(1), 2016, 3035-3074

DOI: http://dx.doi.org/10.23969/litigasi.v17i1.83

\section{PENDAHULUAN}

Undang-Undang Nomor 7 tahun 1992 tentang Perbankan,

sebagaimana telah diubah dengan Undang-Undang Nomor 10 tahun 1998 tentang Perubahan Atas Undang-Undang Nomor 7 Tahun 1992 tentang Perbankan, mengklasifikasikan bank menjadi 2 (dua) kelompok yaitu Bank Umum dan Bank Perkreditan Rakyat. Klasifikasi pembeda di antara keduanya dikarenakan Bank umum dapat berperan serta dalam lalu lintas pembayaran. Oleh karenanya, Bank Umum senantiasa mengembangkan produk serta jasa layanannya untuk melancarkan lalu lintas pembayaran. Salah satu jasa layanan perbankan yang saat ini banyak digunakan oleh masyarakat adalah traveller's cheque atau cek lawatan. Cek lawatan memiliki sifat yang fleksibel, mudah dialihkan dan tidak mengenal daluarsa, sehingga berpotensi untuk disalahgunakan oleh nasabah yang beritikad buruk, misalnya sebagai sarana pemberian suap bagi pejabat negara, sebagai bentuk gratifikasi, dan media pencucian uang.

Penyalahgunaan traveller's cheque oleh nasabah, menimbulkan transaksi ilegal dan hal ini lebih lanjut menimbulkan risiko bagi bank. Dari berbagai risiko yang mungkin timbul, risiko hukum, risiko kepatuhan dan risiko reputasi adalah risikorisiko yang berkaitan erat dengan transaksi ilegal yang terjadi. Di Indonesia, telah berlaku berbagai peraturan berkenaan dengan kewajiban menerapkan manajemen risiko bagi Bank Umum diantaranya Peraturan Bank Indonesia (selanjutnya disebut PBI) Nomor 11/25/PBI/2009 tentang Perubahan Atas Peraturan Bank Indonesia Nomor 5/8/PBI/2003 tentang Penerapan Manajemen Risiko Bagi Bank Umum. 
Available online at: http://ejournal.unpas.ac.id/index.php/litigasi

Litigasi, Vol. 17(1), 2016, 3035-3074

DOI: http://dx.doi.org/10.23969/litigasi.v17i1.83

Peraturan tersebut bersifat umum dan belum memperhatikan kekhususan karakteristik dari transaksi tertentu. Di samping ketentuan tentang manajemen risiko, terdapat di dalam PBI Nomor 3/10/PBI/2001 tentang Penerapan Prinsip Mengenal Nasabah, sebagaimana telah diubah melalui Peraturan Bank Indonesia Nomor 3/23/PBI/2001 dan PBI Nomor 5/21/PBI/2003.

Peraturan perbankan sebagaimana dimaksud di atas, berupaya untuk meminimalisasi kejahatan perbankan berupa penyalahgunaan traveller's cheque oleh nasabah secara ilegal, akan tetapi didalam praktik kondisi demikian masih marak terjadi sehingga perlu dilakukan kajian secara komprehensif untuk menata kembali berbagai aturan yang ada dengan pendekatan manajemen risiko sebagai sebuah disiplin ilmu. Sasaran atau target dari kajian ini diharapkan dapat memberikan suatu temuan baru mengenai bentuk regulasi yang tepat dan sistem operasional yang harus dilakukan oleh pihak bank agar dapat mengantisipasinya untuk menjaga sistem keuangan yang sehat dan terhindar dari kejahatan korporasi.

Adapun sasaran atau target yang hendak dicapai dalam kajian multidisipliner ini adalah:

1. Standard Operational Procedure yang tepat dalam penerbitan dan pencairan traveller's cheque untuk mengantisipasi transaksi ilegal yang menimbulkan risiko bagi bank.

2. Sistem dalam mengantisipasi penyalahgunaan traveller's cheque sebagai instrumen surat berharga yang bersifat fleksibel.

Copyright @ 2016 , LITIGASI, p-ISSN: 0853-7100; e-ISSN: 2442-2274 
Available online at: http://ejournal.unpas.ac.id/index.php/litigasi

Litigasi, Vol. 17(1), 2016, 3035-3074

DOI: http://dx.doi.org/10.23969/litigasi.v17i1.83

3. Sistem manajemen risiko yang tepat dalam transaksi penerbitan dan pencairan traveller's cheque untuk mencegah timbulnya tindak pidana di bidang perbankan.

Penerapan peraturan tentang manajemen risiko memiliki sifat preventif. Hal ini berarti apabila suatu bank melakukan pengelolaan risiko secara benar, bank tersebut dapat terhindar dari terjadinya transaksi-transaksi ilegal termasuk tindak pidana yang menjadikan bank sebagai sasaran dan sarana melakukan tindak pidana tersebut. Penerapan peraturan tentang manajemen risiko perlu dikonkritkan dalam aturan internal perbankan yakni dalam bentuk Standard Operational Procedure yang berlaku bagi setiap transaksi. Berdasarkan gambaran di atas, maka dapat dirumuskan permasalahan terkait bilamana transaksi penerbitan dan pencairan traveller's cheque dapat dikategorikan sebagai transaksi ilegal yang menimbulkan risiko bagi bank, risiko apa saja yang dihadapi oleh bank sehubungan dengan transaksi penerbitan dan pencairan traveller's cheque yang bersifat ilegal dan bagaimana penerapan sistem manajemen risiko dalam transaksi penerbitan dan pencairan traveller's cheque untuk mencegah timbulnya tindak pidana di bidang perbankan.

\section{METODE PENELITIAN}

Metode Penelitian yang digunakan dalam penelitian ini menggunakan pendekatan yuridis normatif, dengan tipe penelitian deskriptif analitis, yaitu dengan cara berusaha memberikan gambaran mengenai permasalahan yang aktual 
Available online at: http://ejournal.unpas.ac.id/index.php/litigasi

Litigasi, Vol. 17(1), 2016, 3035-3074

DOI: http://dx.doi.org/10.23969/litigasi.v17i1.83

berdasarkan fakta-fakta yang tampak. Selanjutnya, metode penelitian digunakan sesuai dengan rumusan masalah yang menjadi fokus penelitian ini.

Penelitian yuridis normatif, yang merupakan penelitian utama dalam penelitian ini, adalah penelitian hukum kepustakaan. Dalam penelitian ini bahan pustaka merupakan data dasar penelitian yang digolongkan sebagai data sekunder. Di dalam penelitian hukum, data sekunder mencakup bahan hukum primer, bahan hukum sekunder, dan bahan hukum tertier.

\section{A. Sekunder}

1. Bahan hukum primer

Bahan hukum primer ini mencakup peraturan perundang-undangan yang terkait dengan manajemen risiko perbankan terkait dengan penerbitan dan pencairan traveller's cheque.

2. Bahan hukum sekunder

Bahan pustaka yang berisikan informasi tentang bahan primer, terdiri atas penjelasan undang-undang yang terkait atas penjelasan undang-undang, literatur tentang perbankan, bahan-bahan seminar yang terkait dengan penerbitan dan pencairan traveller's cheque.

3. Bahan hukum tertier

Bahan hukum penunjang yang memberikan petunjuk terhadap bahan hukum primer dan bahan hukum sekunder, terdiri atas; kamus hukum BelandaIndonesia, Black's Law Dictionary, Collin Dictionary.

Copyright @ 2016 , LITIGASI, p-ISSN: 0853-7100; e-ISSN: 2442-2274 
Available online at: http://ejournal.unpas.ac.id/index.php/litigasi

Litigasi, Vol. 17(1), 2016, 3035-3074

DOI: http://dx.doi.org/10.23969/litigasi.v17i1.83

B. Data Primer

I. Wawancara dengan pejabat-pejabat di Bank Indonesia yang berwenang dalam bidang pengawasan perbankan dan penerbitan traveller's cheque.

II. Wawancara dengan para pejabat di beberapa bank yang bertanggungjawab atas implementasi manajemen risiko dalam penerbitan traveller's cheque.

Populasi dari penelitian ini adalah pejabat Bank Indonesia yang berwenang di bidang pengawasan perbankan dan para pejabat di beberapa bank. Sedangkan teknik pengambilan sampel dilakukan dengan cara teknik sampel purposif (purposive sampling). Wawancara dilakukan di Bank-Bank Swasta yang berada di wilayah kota Bandung.

Teknik pengumpulan data dengan cara wawancara (interview). Wawancara dilakukan dengan komunikasi langsung, yaitu dengan mengadakan hubungan secara langsung dengan objek penelitian, yaitu pejabat di Bank Indonesia yang berwenang di bidang pengawasan perbankan dan pejabat di bank yang bertanggungjawab atas implementasi manajemen risiko dalam penerbitan dan pencairan traveller's cheque. Di samping itu, digunakan pula wawancara dengan komunikasi tidak langsung, untuk batas-batas tertentu, di mana terdapat keterbatasan jarak dan/atau waktu komunikasi dengan objek penelitian. Sehubungan dengan prioritas dari teknik pengumpulan data menggunakan wawancara dengan komunikasi langsung, maka alat pengumpulan data menggunakan pedoman wawancara (interview guide).

Copyright $\odot$ 2016, LITIGASI, p-ISSN: 0853-7100; e-ISSN: 2442-2274 
Available online at: http://ejournal.unpas.ac.id/index.php/litigasi

Litigasi, Vol. 17(1), 2016, 3035-3074

DOI: http://dx.doi.org/10.23969/litigasi.v17i1.83

Teknik analisis digunakan dengan pendekatan kualitatif. Dalam pendekatan kualitatif ini tidak digunakan parameter statistik. Metode deduktif digunakan untuk data yang diperoleh dari penelusuran kepustakaan, sedangkan metode induktif digunakan untuk data yang diperoleh dari lapangan dan besifat pelengkap saja dalam penelitian ini. Untuk data primer hasil wawancara di analisis dengan mengkaitkan teori dan peraturan perundang-undangan.

\section{HASIL PENELITIAN DAN ANALISIS}

A. Pengkualifikasian Tindakan Melawan Hukum Dalam Transaksi Ilegal Dalam Penerbitan Dan Pencairan Traveller's Cheque Yang Menimbulkan Risiko Bagi Bank

Secara garis besar, transaksi yang terkait dengan travel cek dapat dikategorikan menjadi transaksi penerbitan travel cek dan transaksi pencairan travel cek. Dalam kedua transaksi tersebut, prinsip kehati-hatian harus diterapkan untuk menghindari risiko-risiko yang mungkin muncul. Prinsip kehatihatian harus diterapkan sejak penyusunan Standard Operational Procedure (selanjutnya disebut SOP) transaksi sampai dengan penerapan/pelaksanaan SOP dalam sebuah transaksi konkrit. Penyimpangan terhadap prinsip kehati-hatian dapat berujung pada terjadinya transaksi ilegal. Tindakan penyimpangan SOP yang terjadi, tidak secara serta merta dapat dikategorikan sebagai tindak pidana. Dalam hal ini, diperlukan tahapan pengkualifkasian tindakan. Hal ini dilakukan

Copyright @ 2016, LITIGASI, p-ISSN: 0853-7100; e-ISSN: 2442-2274 
Available online at: http://ejournal.unpas.ac.id/index.php/litigasi

Litigasi, Vol. 17(1), 2016, 3035-3074

DOI: http://dx.doi.org/10.23969/litigasi.v17i1.83

untuk mengetahui kapan suatu tindakan penyimpangan SOP termasuk dalam tindak pidana atau tidak.

Tindak pidana atau yang diistilahkan dengan "strafbar feit", dapat diterjemahkan pula sebagai "kenyataan yang dapat dipidana" mengandung pengertian adanya keterkaitan dengan syarat pemidanaan. Syarat-syarat yang harus dipenuhi sehubungan dengan dapat atau tidak dijatuhkannya sanksi pidana yaitu:

\section{Unsur subjektif :}

Unsur subjektif adalah unsur-unsur yang melekat pada diri si pelaku atau yang berhubungan dengan diri si pelaku, termasuk segala sesuatu yang terkandung di dalam hatinya (Lamintang, 1996 : 193). Artinya, pidana dapat dijatuhkan apabila seseorang memenuhi unsur schuld (kesalahan). Menurut Andi Hamzah, kesalahan dalam arti luas meliputi:

\section{a. Sengaja}

Kesengajaan atau kealpaan merupakan unsur dari adanya kesalahan. Menurut Memorie van Toelichting, kesengajaan sama dengan "willens en wettens" atau diketahui dan dikehendaki. Satochid Kartanegara berpendapat bahwa yang dimaksud willens en wettens adalah seseorang yang melakukan suatu perbuatan dengan sengaja harus menghendaki perbuatan itu serta menginsyafi atau mengerti akan akibat dari perbuatan itu (Mahrus Ali, 2011 : 174).

Copyright @ 2016 , LITIGASI, p-ISSN: 0853-7100; e-ISSN: 2442-2274 
Available online at: http://ejournal.unpas.ac.id/index.php/litigasi

Litigasi, Vol. 17(1), 2016, 3035-3074

DOI: http://dx.doi.org/10.23969/litigasi.v17i1.83

b. Kelalaian

Suatu perbuatan mengandung unsur culpa apabila pelaku tidak berhati-hati melakukan suatu perbuatan, disamping dapat menduga akibatnya. Kealpaan terjadi apabila seseorang tetap melakukan perbuatan itu meskipun ia telah mengetahui atau menduga akibatnya. Keadaan batin pelaku perbuatan pidana bersifat ceroboh, teledor atau kurang hati-hati sehingga perbuatan dan akibat yang dilarang oleh hukum terjadi (Mahrus Ali, $2011: 177)$.

c. Dapat dipertanggungjawabkan.

Ketiga-tiganya merupakan unsur subyektif syarat pemidanaan.

2. Unsur objektif.

Unsur objektif adalah unsur yang ada hubungannya dengan keadaan-keadaan di mana tindakan si pelaku tersebut dilakukan. Termasuk dalam unsur objektif dari suatu tindak pidana adalah :

a. sifat melawan hukum (wederechtelijk),

b. kualitas dari pelaku,

c. kausalitas.

Dikaitkan dengan syarat-syarat pemidanaan di atas, keberadaan SOP menjadi penting, karena SOP merupakan pedoman pelaksanaan transaksi. Adanya penyimpangan terhadap SOP merupakan salah satu petunjuk apakah terdapat unsur kesalahan, baik yang didasari oleh kesengajaan ataupun kelalaian. Selain perlu memperhatikan keberadaan SOP, pengkualifikasian tindak pidana dalam

Copyright @ 2016 , LITIGASI, p-ISSN: 0853-7100; e-ISSN: 2442-2274 
Available online at: http://ejournal.unpas.ac.id/index.php/litigasi

Litigasi, Vol. 17(1), 2016, 3035-3074

DOI: http://dx.doi.org/10.23969/litigasi.v17i1.83

transaksi penerbitan dan pencairan travel cek secara mutlak berpedoman pada rumusan delik yang terdapat dalam perundang-undangan tertulis, dalam hal ini Undang-Undang Perbankan.

Berikut akan dipaparkan bagaimana prinsip kehati-hatian harus diterapkan dalam SOP transaksi, kemudian bagaimana jika terjadi penyimpangan atau pelanggaran terhadap SOP tersebut dalam sebuah transaksi konkrit, apakah hal tersebut dapat dikualifikasikan sebagai tindak pidana sebagaimana dimaksud dalam Undang-undang Perbankan.

Di dalam ranah hukum pidana, pengkualifikasian suatu tindakan sebagai perbuatan pidana, dilandasi oleh asas legalitas. Suatu perbuatan dapat dinyatakan sebagai perbuatan pidana apabila telah diatur oleh ketentuan pidana yang lebih dahulu ada sebelum perbuatan dilakukan. Dari penelusuran kaidah hukum yang penulis lakukan, rumusan peraturan pidana yang terkait dengan penerapan prinsip kehati-hatian dalam perbankan adalah:

Pasal 49 ayat (2) butir b Undang-Undang Perbankan:

"Anggota Dewan Komisaris, Direksi atau pegawai bank yang dengan sengaja tidak melaksanakan langkah-langkah yang diperlukan untuk memastikan ketaatan bank terhadap ketentuan dalam undang-undang ini dan ketentuan peraturan perundang-undangan lainnya yang berlaku bagi bank, diancam dengan pidana penjara sekurang-kurangnya 3 (tiga) tahun dan paling lama 8 (delapan) tahun serta denda sekurang-kurangnya Rp5.000.000.000,00 (lima miliar rupiah) dan paling banyak Rp100.000.000.000,00 (seratus miliar rupiah)"

Copyright (C) 2016, LITIGASI, p-ISSN: 0853-7100; e-ISSN: 2442-2274 
Available online at: http://ejournal.unpas.ac.id/index.php/litigasi

Litigasi, Vol. 17(1), 2016, 3035-3074

DOI: http://dx.doi.org/10.23969/litigasi.v17i1.83

Pasal $51(1)$ :

"Tindak pidana sebagaimana dimaksud dalam Pasal 46, Pasal 47, Pasal 47A, Pasal 48 ayat (1), Pasal 49, Pasal 50, dan Pasal 50A adalah kejahatan."

Sebagai tindak pidana yang dikategorikan sebagai kejahatan, unsur-unsur delik yang terdapat dalam pasal 49 ayat (2) butir b UU Perbankan yaitu:

a. Anggota Dewan Komisaris, Direksi atau pegawai bank;

b. yang dengan sengaja;

c. tidak melaksanakan langkah-langkah yang diperlukan untuk memastikan ketaatan bank terhadap ketentuan dalam undang-undang ini dan ketentuan peraturan perundang-undangan lainnya yang berlaku bagi bank.

Untuk menyatakan apakah suatu transaksi ilegal yang terjadi sehubungan dengan penerbitan dan pencairan travel cek memenuhi unsur-unsur delik di atas, maka penulis akan melakukan analisa sebagai berikut:

Anggota Dewan Komisaris, Direksi atau pegawai bank harus memiliki sikap batin berupa kesengajaan untuk tidak mentaati peraturan perundang-undangan. Menurut Memorie van Toelichting, kesengajaan sama dengan "willens en wettens" atau mengetahui dan menghendaki. Satochid Kartanegara berpendapat bahwa yang dimaksud willens en wettens adalah seseorang yang melakukan suatu perbuatan dengan sengaja harus menghendaki perbuatan itu serta menginsyafi atau mengerti akan akibat dari perbuatan itu (Mahrus Ali, 2011 : 174). Unsur kesengajaan nampak dalam hal:

Copyright @ 2016 , LITIGASI, p-ISSN: 0853-7100; e-ISSN: 2442-2274 
Available online at: http://ejournal.unpas.ac.id/index.php/litigasi

Litigasi, Vol. 17(1), 2016, 3035-3074

DOI: http://dx.doi.org/10.23969/litigasi.v17i1.83

a. Substansi SOP yang diberlakukan oleh bank tidak sesuai dengan persyaratan minimum sebagaimana ditetapkan oleh Bank Indonesia.

Terkait dengan pembahasan tentang ketentuan minimum penerapan prinsip kehati-hatian yang ditetapkan oleh Bank Indonesia, dalam bagian ini penulis menjelaskan bahwa standar minimum penerapan prinsip kehati-hatian dalam SOP mengacu pada Pasal 8 PBI APU-PPT yang menyatakan: "Dalam menerapkan program APU dan PPT, Bank wajib memiliki kebijakan dan prosedur tertulis yang paling kurang mencakup: a) permintaan informasi dan dokumen ; b) Beneficial Owner ; c) verifikasi dokumen; d) CDD yang lebih sederhana; e) penutupan hubungan dan penolakan transaksi; f) ketentuan mengenai area beresiko tinggi dan PEP; g) pelaksanaan CDD oleh pihak ketiga; h) pengkinian dan pemantauan; i) Cross Border Correspondent Banking; j)transfer dana; dan k) penatausahaan dokumen."

Penulis berpendapat apabila hal ini terjadi, berarti telah terjadi kesalahan pada tahapan penyusunan kebijakan. Tahapan penyusunan kebijakan dilakukan dengan suatu mekanisme yang terencana, melibatkan berbagai unsur di dalam struktur organisasi perbankan. Artinya, tindakan tersebut dilakukan dengan suatu kesengajaan. Pihak bank seharusnya mengetahui apa akibat yang akan muncul dari diberlakukannya kebijakan yang salah. Apabila bank tidak menghendaki munculnya akibat tersebut (yakni terjadinya transaksi ilegal), seharusnya bank mentaati peraturan yang berlaku dalam penyusunan SOP transaksi.

Copyright @ 2016 , LITIGASI, p-ISSN: 0853-7100; e-ISSN: 2442-2274 
Available online at: http://ejournal.unpas.ac.id/index.php/litigasi

Litigasi, Vol. 17(1), 2016, 3035-3074

DOI: http://dx.doi.org/10.23969/litigasi.v17i1.83

b. Pelanggaran SOP terjadi dengan sepengetahuan dan persetujuan pejabat bank yang bertugas untuk mengawasi transaksi.

Penaatan terhadap SOP sebagai implementasi dari prinsip kehati-hatian menjadi tanggungjawab bersama dari pegawai dan pejabat bank sesuai dengan jenjang jabatan mereka masing-masing. Apabila dikaitkan dengan proses penerbitan dan pencairan travel cek, dalam hal SOP mensyaratkan transaksi tersebut dilakukan dengan sepengetahuan dari pejabat bank pada kedudukan tertentu, (misalnya dalam transaksi dengan nominal kumulatif tertentu), maka dalam hal pegawai lalai menerapkan SOP, perlu ditentukan terlebih dahulu apakah terdapat kesengajaan dari pihak pejabat yang diharuskan melakukan pemeriksaan atas keabsahan transaksi yang harus berlangsung dengan sepengetahuannya. Jika pejabat bank tersebut menyetujui tindakan bawahannya yang mengandung pelanggaran SOP atau jika pejabat bank menyetujui terjadinya transaksi yang dapat dikategorikan sebagai transaksi ilegal, artinya unsur kesengajaan terpenuhi.

Menurut pendapat dari Lamintang, dalam hal terjadinya pelanggaran, pengurus atau komisaris pada suatu korporasi hanya dapat dihukum jika pelanggaran tersebut terjadi dengan sepengetahuan mereka. Artinya, berdasarkan teori, jika kelalaian menerapkan prinsip kehati-hatian terjadi dengan sepengetahuan pejabat bank yang pada menduduki tingkat jabatan tertentu dan bertanggungjawab dalam hal pengawasan, maka pejabat bank

Copyright @ 2016 , LITIGASI, p-ISSN: 0853-7100; e-ISSN: 2442-2274 
Available online at: http://ejournal.unpas.ac.id/index.php/litigasi

Litigasi, Vol. 17(1), 2016, 3035-3074

DOI: http://dx.doi.org/10.23969/litigasi.v17i1.83

tersebut dapat dipidana (Lamintang, 1996 : 211). Sedangkan untuk kondisikondisi di bawah ini, penulis berpendapat bahwa unsur kesengajaan tidak terpenuhi. Kondisi yang dimaksud diantaranya:

a. SOP sudah sesuai dengan ketentuan minimum penerapan prinsip kehatihatian yang ditetapkan oleh Bank Indonesia, SOP ditaati dan diterapkan secara benar, namun transaksi ilegal tetap terjadi akibat:

1) karakteristik dari transaksi yang memang memiliki celah untuk disalahgunakan, atau

2) karena keahlian pelaku yang sangat tinggi dan berada di luar jangkauan kewajiban petugas bank dalam melakukan "penghati-hati" atau "penduga-duga".

Jika kondisi di atas terpenuhi, maka pihak bank tidak memiliki unsur "schuld" (baik berupa kesengajaan maupun kelalaian). Oleh sebab itu, transaksi ilegal yang terjadi merupakan tindak pidana yang dilakukan oleh nasabah secara pribadi. Dihubungkan dengan kualifikasi tindak pidana, penulis mengutip pendapat dari Fadil Zumhanna yang menyatakan bahwa jika SOP sebagai self regulatory banking telah ditaati dengan itikad baik, dan kemudian terjadi risiko, maka hal tersebut merupakan normal business risk yang masuk dalam penanganan rezim hukum perdata belaka (Fadil Zumhana, $2011: 17)$.

Copyright @ 2016, LITIGASI, p-ISSN: 0853-7100; e-ISSN: 2442-2274 
Available online at: http://ejournal.unpas.ac.id/index.php/litigasi

Litigasi, Vol. 17(1), 2016, 3035-3074

DOI: http://dx.doi.org/10.23969/litigasi.v17i1.83

b. Pelanggaran SOP terjadi semata-mata karena kelalaian pihak pegawai bank; Suatu perbuatan mengandung unsur culpa apabila pelaku tidak berhati-hati melakukan suatu perbuatan, disamping dapat menduga akibatnya. Kealpaan terjadi apabila seseorang tetap melakukan perbuatan itu meskipun ia telah mengetahui atau menduga akibatnya. Keadaan batin pelaku perbuatan pidana bersifat ceroboh, teledor atau kurang hati-hati sehingga perbuatan dan akibat yang dilarang oleh hukum terjadi (Fadil Zumhana, $2011: 17)$.

Jika perbuatan pegawai bank tersebut didasari oleh kelalaian, maka tindakan pelanggaran terhadap SOP tidak dapat dikualifikasikan sebagai perbuatan pidana, karena tidak memenuhi unsur-unsur dalam Pasal 49 ayat (2) butir b UU Perbankan.

Berdasarkan ajaran kausalitas, ditentukan apakah seseorang betul-betul bertanggungjawa $b$ atas terjadinya suatu tindak pidana atau dengan kata lain apakah orang tersebut merupakan sebab dari terjadinya tindak pidana. Menurut ajaran dari Von Buri, dinyatakan bahwa seluruh syarat adalah sama dengan sebab (Jan Remmelink, 2003 : 127). Namun diperlukan pembatasan bagi penerapan teori tersebut. Yang dianggap sebagai penyebab adalah tindakan yang didalamnya mengandung unsur kesalahan. Menurut Teori Relevansi, sebab yang diperhitungkan adalah yang mengandung dolus atau culpa (Jan Remmelink, 2003 : 129). Undang-Undang Perbankan 
Available online at: http://ejournal.unpas.ac.id/index.php/litigasi

Litigasi, Vol. 17(1), 2016, 3035-3074

DOI: http://dx.doi.org/10.23969/litigasi.v17i1.83

membatasi secara lebih ketat bahwa yang dianggap sebagai delik adalah tindakan-tindakan yang didasari oleh kesengajaan. Pihak pegawai bank yang semata-mata lalai hanya dianggap sebagai "unsur tambahan" yang memudahkan terjadinya tindak pidana tersebut. Undang-undang tidak mengarahkan pertanggungjawaban pidana pada keteledoran atau ketidakhatihatian dari pegawai bank tersebut. Undang-Undang Perbankan membebankan pertanggungawaban pidana hanya pada pihak-pihak yang diyakini memiliki sikap batin / niat jahat.

Unsur terakhir dalam Pasal 49 ayat (2) butir b Undang-Undang Perbankan yang harus diuraikan adalah unsur "tidak melaksanakan langkah-langkah yang diperlukan untuk memastikan ketaatan bank terhadap ketentuan dalam undang-undang perbankan dan perundang-undang lainnya bagi bank". Dalam Undang-Undang Perbankan tidak dijelaskan pengertian dari frasa "langkahlangkah yang diperlukan untuk memastikan ketaatan bank terhadap ketentuan perundang-undangan". Karena tidak terdapat definisi otentik di dalam Undang-Undang tentang Perbankan, untuk memaknai frasa tersebut perlu dilakukan penafsiran hukum. Apabila ditafsirkan secara gramatikal, frasa tersebut bermakna luas dan tidak terdefinisi secara jelas batasan-batasan pengertian "langkah-langkah yang diperlukan." Tidak ada pembatasan mengenai tindakan apa yang dianggap perlu dan tindakan apa yang dianggap tidak perlu dilakukan. Secara gramatikal, “langkah-langkah yang diperlukan” 
Available online at: http://ejournal.unpas.ac.id/index.php/litigasi

Litigasi, Vol. 17(1), 2016, 3035-3074

DOI: http://dx.doi.org/10.23969/litigasi.v17i1.83

bermakna tindakan-tindakan yang memang harus dilakukan untuk mencapai tujuan tertentu. Dikaitkan dengan adanya tujuan, rumusan pasal ini memiliki tujuan sosial yaitu tercapainya sistem perbankan nasional yang sehat, yang didukung oleh ketaatan bank terhadap ketentuan perundang-undangan.

Berdasarkan analisa tersebut, penulis menyimpulkan bahwa frasa "langkahlangkah yang diperlukan untuk memastikan ketaatan bank terhadap ketentuan dalam undang-undang perbankan dan perundang-undang lainnya bagi bank" mencakup segala tindakan yang menjadi kewajiban Anggota Dewan Komisaris, Direksi atau pegawai bank sebagaimana diatur secara eksplisit dalam peraturan perundang-undangan, Peraturan Bank Indonesia, Surat Edaran Bank Indonesia, dan peraturan internal dari bank yang bersangkutan, ditambah dengan segala tindakan yang tidak diatur di dalam perundangundangan tertulis, namun berdasarkan kebiasaan dan kepatutan menjadi kewajiban dari pihak-pihak tersebut. Apabila langkah-langkah tersebut tidak dilaksanakan, Anggota Dewan Komisaris, Direksi atau pegawai bank dapat dikenai pertanggungjawaban pidana. Anggota Dewan Komisaris dan Direksi terikat pula pada kepatutan dalam pengelolaan perusahaan yang keberlakuannya telah diakui dalam praktik pengelolaan bisnis diantaranya prinsip Fiduciary Duty (asas kepercayaan), itikad baik dan kehati-hatian.

Copyright @ 2016 , LITIGASI, p-ISSN: 0853-7100; e-ISSN: 2442-2274 
Available online at: http://ejournal.unpas.ac.id/index.php/litigasi

Litigasi, Vol. 17(1), 2016, 3035-3074

DOI: http://dx.doi.org/10.23969/litigasi.v17i1.83

B. Risiko Bank Sehubungan Dengan Transaksi Penerbitan Dan Pencairan Traveller's Cheque Yang Bersifat Ilegal

Bank dalam menjalankan kegiatannya tidak dapat dilepaskan dari berbagai risiko. Risiko yang timbul dapat disebabkan oleh berbagai faktor. Faktor yang paling mendasar timbulnya risiko bank adalah tidak dilaksanakannya prudential banking (prinsip kehati-hatian). Oleh sebab itu, guna meminimalisir risiko yang lebih besar, dikembangkanlah Management Risk (risiko manajemen). Risiko manajemen perbankan adalah risiko yang dapat membawa pengaruh yang merugikan sehingga mengurangi profitabilitas sumber keuangan bank, akibatnya muncul ketidakpastian dalam upaya meraih keuntungan (profit). Untuk itu, perlu pengalaman yang memadai dalam mengkalkulasi kemungkinan munculnya risiko manajemen yang setiap saat merupakan ancaman terhadap profitabilitas. Profitabilitas sangat berkait erat dengan masalah akuntansi dan akurasi pengukuran sasaran pasar. Fokus utama risiko manajemen perbankan adalah risiko-risiko yang berhubungan dengan masalah finansial. Risiko tersebut berkaitan dengan pergerakan pasar, dan berpengaruh langsung terhadap operasional sebuah bank. IImu risiko manajemen perbankan ditujukan untuk melindungi seluruh organisasi perbankan yang malfungsi, sebab hal ini akan membawa konsekuensi besar terhadap kelangsungan hidup sebuah bank (Wawan Purwanto, 2011 : 67). Manajemen risiko dalam kegiatan operasional bank diatur dalam PBI Nomor 5/8/PBI/2003 tanggal 19 Mei 2003 tentang Penerapan Manajemen Risiko Bagi Bank Umum. Dikaitkan dengan transaksi

Copyright @ 9 2016, LITIGASI, p-ISSN: 0853-7100; e-ISSN: 2442-2274 
Available online at: http://ejournal.unpas.ac.id/index.php/litigasi

Litigasi, Vol. 17(1), 2016, 3035-3074

DOI: http://dx.doi.org/10.23969/litigasi.v17i1.83

penerbitan dan pencairan travel cek, maka di antara berbagai macam risiko yang ada, 4 (empat) diantaranya memiliki korelasi yang cukup signifikan, yaitu:

\section{Risiko Operasional}

Risiko Operasional adalah risiko yang antara lain disebabkan adanya ketidakcukupan dan atau tidak berfungsinya proses internal, kesalahan manusia, kegagalan sistem atau adanya problem eksternal yang mempengaruhi operasional bank. Transaksi penerbitan dan pencairan travel cek dalam praktiknya banyak melibatkan pihak dan dalam prosesnya secara spesifik, penerbitan dan pencairan travel cek rentan terhadap tindak pidana, oleh karenanya proses internal maupun faktor sumber daya manusia, dan sistem yang digunakan harus dalam kondisi dan atau kualifikasi yang baik. Lemahnya proses internal dan kemampuan sumber daya manusia, serta sistem yang ada risiko operasional yang akan dihadapi bank akan semakin besar.

\section{Risiko Hukum}

Risiko hukum adalah risiko yang disebabkan oleh adanya kelemahan aspek yuridis. Kelemahan aspek yuridis antara lain disebabkan adanya tuntutan hukum, ketiadaan peraturan perundang-undangan yang mendukung atau kelemahan perikatan seperti tidak dipenuhinya syarat sahnya kontrak dan pengikatan agunan yang tidak sempurna.

Copyright @ C 2016, LITIGASI, p-ISSN: 0853-7100; e-ISSN: 2442-2274 
Available online at: http://ejournal.unpas.ac.id/index.php/litigasi

Litigasi, Vol. 17(1), 2016, 3035-3074

DOI: http://dx.doi.org/10.23969/litigasi.v17i1.83

Bank dalam menjalankan kegiatan operasionalnya diatur oleh seperangkat norma-norma yang disebut dengan peraturan-perundangan, di mana peraturan perundang-undangan sebagaimana dimaksud tersusun secara hierarkis. Peraturan perundang-undangan berperan sebagai pedoman yang berfungsi mengatur bank agar dalam menjalankan kegiatannya sesuai dengan norma yang telah ditetapkan dan tidak merugikan kepentingan masyarakatt. Substansi dalam peraturan-perundang-undangan merupakan hukum yang harus dipatuhi bank. Khusus dalam transaksi penerbitan dan pencairan travel cek, seperangkat aturan hukum yang mengatur transaksi tersebut perlu dikaji secara berkesinambungan mengikuti perkembangan bisnis perbankan dan dinamika masyarakat, serta pentingnya instrument-instrumen pendukung seperti perjanjian yang melindungi kepentingan pihak bank agar transaksi sebagaimana dimaksud tidak mudah disalahgunakan oleh pihakpihak yang tidak bertanggungjawab. Oleh karenanya, manajemen dalam menghadapi risiko hukum menjadi sangat penting, agar risiko yang dihadapi bank dapat diminimalisir.

\section{Risiko Reputasi}

Risiko reputasi adalah risiko yang antara lain disebabkan adanya pulikasi negatif yang terkait dengan kegiatan usaha bank atau persepsi negatif terhadap bank. Keberlangsungan hidup suatu bank terletak pada reputasi bank bersangkutan. Dalam transaksi penerbitan dan pencairan travel cek,

Copyright @ 2016 , LITIGASI, p-ISSN: 0853-7100; e-ISSN: 2442-2274 
Available online at: http://ejournal.unpas.ac.id/index.php/litigasi

Litigasi, Vol. 17(1), 2016, 3035-3074

DOI: http://dx.doi.org/10.23969/litigasi.v17i1.83

pihak-pihak internal maupun eksternal dapat berpotensi mempengaruhi reputasi bank, seperti contoh adanya oknum pegawai bank yang melakukan tindakan pelanggaran yang berdampak pada reputasi bank.

\section{Risiko Kepatuhan}

Risiko kepatuhan adalah risiko yang disebabkan bank tidak mematuhi atau tidak melaksanakan peraturan perundang-undangan dan ketentuan lain yang berlaku. Pengelolaan risiko kepatuhan dilakukan melalui penerapan sistem pengendalian intern secara konsisten. Kepatuhan terhadap peraturan perundang-undangan merupakan bentuk perwujudan prudential banking. Prudential banking merupakan sesuatu yang wajib dilaksanakan oleh bank, mengingat ketidakpatuhan terhadap peraturan perundang-undangan berarti telah mengabaikan aturan dan prinsip kehati-hatian. Ketidakpatuhan terhadap peraturan perundang-undangan dapat dikualifikasikan sebagai pelanggaran dan atau kejahatan yang lebih jauh berdampak pada sanksi. Ketidakpatuhan juga akan memiliki korelasi yang cukup signifikan dengan risiko reputasi. Untuk itu guna meminimalisir risiko yang ada, makan manajemen risiko menjadi sesuatu yang cukup penting.

Terkait transaksi penerbitan dan pencairan Traveller's Cheque yang bersifat ilegal, apabila telah terjadi transaksi ilegal karena adanya pelanggaran SOP dengan sepengetahuan dan persetujuan pejabat bank yang bertugas untuk mengawasi transaksi oleh pegawai bank tugas secara sengaja, maka perbuatan

Copyright $\odot$ 2016, LITIGASI, p-ISSN: 0853-7100; e-ISSN: 2442-2274 
Available online at: http://ejournal.unpas.ac.id/index.php/litigasi

Litigasi, Vol. 17(1), 2016, 3035-3074

DOI: http://dx.doi.org/10.23969/litigasi.v17i1.83

tersebut telah memenuhi unsur sebagaimana dimaksud dalam Pasal 49 ayat (2)

butir b UU Perbankan. Maka bagi pejabat bank yang bersangkutan dapat dikenakan sanksi pidana, sedangkan di sisi lain Bank terkait dapat dikenakan sanksi administratif berdasarkan peraturan peundang-undangan.

C. Penerapan Sistem Manajemen Risiko Dalam Transaksi Penerbitan Dan Pencairan Traveller's Cheque Untuk Mencegah Timbulnya Tindak Pidana Di Bidang Perbankan

Implementasi Customer Due Dillegence terkait penerapan manajemen risiko dalam transaksi penerbitan dan pencairan travel cek dapat dirangkum sebagai berikut:

a. Transaksi penerbitan travel cek

\begin{tabular}{|c|c|c|c|}
\hline No & $\begin{array}{l}\text { Penerapan Prinsip } \\
\text { Kehati-hatian } \\
\text { menurut Peraturan } \\
\text { Bank Indonesia }\end{array}$ & $\begin{array}{l}\text { Penerapan Prinsip Kehati-hatian dalam } \\
\text { Standar Operational Procedure Bank }\end{array}$ & $\begin{array}{c}\text { Petugas Bank } \\
\text { yang } \\
\text { bertanggungjawab }\end{array}$ \\
\hline 1 & $\begin{array}{l}\text { Berdasarkan Surat } \\
\text { Edaran Bank } \\
\text { Indonesia No.8 / } \\
35 \text { / DASP tanggal } \\
22 \text { Desember } \\
2006 \text { perihal } \\
\text { Warkat Debet dan } \\
\text { Dokumen Kliring } \\
\text { serta } \\
\text { Pencetakannya } \\
\text { pada Perusahaan } \\
\text { Percetakan Warkat } \\
\text { dan Dokumen } \\
\text { Kliring: } \\
\text { Persiapan dan } \\
\text { pencetakan warkat } \\
\text { cek perjalanan } \\
\text { harus memenuhi }\end{array}$ & $\begin{array}{l}\text { Tahap persiapan warkat travel cek: } \\
\text { a. melakukan cross check atas nomor seri } \\
\text { lembar-lembar travel cek yang akan } \\
\text { dijual, dengan catatan stock yang } \\
\text { tersedia pada bank, dan catatan transaksi } \\
\text { travel cek yang pernah terjadi, untuk } \\
\text { mencegah adanya travel cek dengan } \\
\text { nomor seri ganda yang akan mempersulit } \\
\text { penelusuran transaksi. } \\
\text { b. memastikan pada travel cek tercantum } \\
\text { tanda tangan dari Direksi bank dan } \\
\text { Pimpinan Cabang. }\end{array}$ & $\begin{array}{l}\text { Tahap persiapan } \\
\text { warkat travel cek } \\
\text { pada tataran } \\
\text { kantor pusat / } \\
\text { cabang menjadi } \\
\text { tanggung jawab } \\
\text { dari Kepala } \\
\text { Operasional } \\
\text { Kantor Pusat / } \\
\text { Cabang }\end{array}$ \\
\hline
\end{tabular}

Copyright $\odot$ 2016, LITIGASI, p-ISSN: 0853-7100; e-ISSN: 2442-2274 


\begin{tabular}{|c|c|c|c|}
\hline & $\begin{array}{l}\text { kriteria } \\
\text { sebagaimana diatur } \\
\text { dalam peraturan } \\
\text { tersebut (Peraturan } \\
\text { tersebut mengatur } \\
\text { spesifikasi jenis } \\
\text { kertas warkat) }\end{array}$ & & \\
\hline $2 a$. & $\begin{array}{l}\text { Berdasarkan PBI } \\
\text { Nomor } \\
11 / 28 / P B I / 2009 \\
\text { tentang Penerapan } \\
\text { Program Anti } \\
\text { Pencucian Uang } \\
\text { dan Pencegahan } \\
\text { Pendanaan } \\
\text { Terorisme Bagi } \\
\text { Bank Umum } \\
\text { (selanjutnya } \\
\text { disebut PBI tentang } \\
\text { APU-PPT), } \\
\text { langkah-langkah } \\
\text { yang harus } \\
\text { dilaksanakan dalam } \\
\text { menerapkan prinsip } \\
\text { kehati-hatian } \\
\text { adalah: } \\
\text { Penerimaan dan } \\
\text { identifikasi nasabah } \\
\text { berdasarkan risk } \\
\text { based approach: } \\
\text { Data nasabah yang } \\
\text { harus diketahui: } \\
\text { a. nama lengkap } \\
\text { b. nomor identitas } \\
\text { c. alamat } \\
\text { d. tempat / tanggal } \\
\text { lahir } \\
\text { e. kewarganegaraan } \\
\text { f. pekerjaan } \\
\text { g. } \\
\text { perkawinan } \\
\text { h. sumber dana } \\
\text { i. penghasilan rata- }\end{array}$ & $\begin{array}{l}\text { Tahap identifikasi dan verifikasi dilakukan } \\
\text { dengan: } \\
\text { Nasabah menandatangani formulir } \\
\text { pembelian travel cek. } \\
\text { Formulir berisi: } \\
\text { a. nama } \\
\text { b. nomor identitas } \\
\text { c. alamat } \\
\text { d. tujuan pembelian } \\
\text { e. jumlah yang dibeli } \\
\text { f. jumlah penghasilan per bulan } \\
\text { g. sumber dana } \\
\text { Nasabah harus menyerahkan kartu } \\
\text { identitas, dan fotokopi kartu identitas } \\
\text { tersebut dilampirkan pada formulir } \\
\text { pembelian dan diarsipkan oleh pihak bank. }\end{array}$ & $\begin{array}{l}\text { Customer } \\
\text { Service, dengan } \\
\text { pemeriksaan dan } \\
\text { pemantauan dari } \\
\text { Supervisor divisi } \\
\text { Customer Service }\end{array}$ \\
\hline
\end{tabular}

Copyright $\odot$ 2016, LITIGASI, p-ISSN: 0853-7100; e-ISSN: 2442-2274 
Available online at: http://ejournal.unpas.ac.id/index.php/litigasi

Litigasi, Vol. 17(1), 2016, 3035-3074

DOI: http://dx.doi.org/10.23969/litigasi.v17i1.83

\begin{tabular}{|c|c|c|c|}
\hline & $\begin{array}{l}\text { rata } \\
\text { j. tujuan transaksi }\end{array}$ & & \\
\hline $2 b$. & $\begin{array}{l}\text { Tahap verifikasi } \\
\text { nasabah yang } \\
\text { tergolong walk in } \\
\text { customers (WIC): } \\
\text { Bank harus } \\
\text { meminta informasi } \\
\text { dari walk in } \\
\text { customers, baik } \\
\text { yang melakukan } \\
\text { transaksi dengan } \\
\text { nominal lebih } \\
\text { maupun kurang } \\
\text { dari } \\
\text { Rp.100.000.000,- } \\
\text { (seratus juta } \\
\text { rupiah). } \\
\text { Rincian data diri } \\
\text { WIC yang diminta } \\
\text { oleh bank sama } \\
\text { dengan rincian data } \\
\text { yang diminta dari } \\
\text { nasabah biasa. }\end{array}$ & $\begin{array}{l}\text { Apabila nominal pembelian secara } \\
\text { kumulatif diatas Rp. } 100.000 .000,- \\
\text { (seratus juta rupiah), maka nasabah harus } \\
\text { mengisi formulir walk in customer. } \\
\text { (SOP ini masih mengacu pada PBI KYC } \\
\text { yang lama dan belum disesuaikan dengan } \\
\text { PBI APU-PPT). }\end{array}$ & $\begin{array}{l}\text { Pimpinan Cabang } \\
\text { atau Kepala } \\
\text { Operasional wajib } \\
\text { mengetahui } \\
\text { transaksi tersebut. }\end{array}$ \\
\hline \multirow[t]{2}{*}{$2 c}$. & \multirow{2}{*}{$\begin{array}{l}\text { Identifikasi } \\
\text { transaksi keuangan } \\
\text { mencurigakan } \\
\text { (suspicious } \\
\text { transaction) dan } \\
\text { transaksi tunai } \\
\text { dalam jumlah } \\
\text { tertentu (cash } \\
\text { transaction). } \\
\text { Macam-macam } \\
\text { transaksi dengan } \\
\text { media travel cek } \\
\text { yang dikategorikan } \\
\text { sebagai transaksi } \\
\text { mencurigakan } \\
\text { menurut Lampiran } \\
\text { III Surat Edaran } \\
\text { Ekstern Bank } \\
\text { Indonesia No. 11/ } \\
31 \text { / DPNP tanggal }\end{array}$} & $\begin{array}{l}\text { Identifikasi ini dilakukan sebelum terjadi } \\
\text { transaksi pembelian travel cek } \\
\text { Jika terdapat dugaan transaksi } \\
\text { mencurigakan, maka pihak bank diwajibkan } \\
\text { melakukan penundaan transaksi. }\end{array}$ & $\begin{array}{l}\text { Keputusan untuk } \\
\text { melakukan } \\
\text { penundaan } \\
\text { transaksi } \\
\text { dinyatakan oleh } \\
\text { Pimpinan Cabang }\end{array}$ \\
\hline & & $\begin{array}{l}\text { Apabila tidak terdapat indikasi terjadinya } \\
\text { transaksi mencurigakan, maka transaksi } \\
\text { pembelian travel cek dapat dilanjutkan. } \\
\text { a. Pihak pembeli yang membeli travel cek } \\
\text { untuk kepentingannya sendiri, ia harus } \\
\text { menandatangani travel cek tersebut di } \\
\text { kolom pembelian dan penandatanganan } \\
\text { dilakukan di hadapan petugas bank. } \\
\text { b. Apabila nasabah membeli travel cek } \\
\text { untuk kepentingan orang lain, maka ia } \\
\text { tidak usah menandatangani travel cek. la } \\
\text { hanya perlu menandatangani formulir } \\
\text { pembelian dan menyatakan bahwa }\end{array}$ & $\begin{array}{l}\text { Transaksi } \\
\text { pembelian travel } \\
\text { cek dilaksanakan } \\
\text { antara nasabah } \\
\text { dengan petugas } \\
\text { Teller bank, } \\
\text { untuk transaksi } \\
\text { dalam nominal } \\
\text { tertentu, } \\
\text { dilakukan dengan } \\
\text { otorisasi dari } \\
\text { pejabat yang } \\
\text { berwenang. }\end{array}$ \\
\hline
\end{tabular}

Copyright (C) 2016, LITIGASI, p-ISSN: 0853-7100; e-ISSN: 2442-2274 
Available online at: http://ejournal.unpas.ac.id/index.php/litigasi

Litigasi, Vol. 17(1), 2016, 3035-3074

DOI: http://dx.doi.org/10.23969/litigasi.v17i1.83

\begin{tabular}{|c|c|c|c|}
\hline & $\begin{array}{l}\text { 30 November } 2009 \\
\text { 1. Penarikan } \\
\text { sejumlah besar } \\
\text { uang dengan } \\
\text { travel cek. } \\
\text { 2. Permintaan } \\
\text { travel cek } \\
\text { dengan frekuensi } \\
\text { tinggi, } \\
\text { 3. Pembayaran } \\
\text { dengan travel } \\
\text { cek dalam } \\
\text { frekuensi tinggi }\end{array}$ & $\begin{array}{l}\text { pembelian travel cek tersebut ditujukan } \\
\text { untuk kepentingan orang lain. }\end{array}$ & \\
\hline 3 & $\begin{array}{l}\text { Penatausahaan } \\
\text { Dokumen } \\
\text { Berdasarkan Pasal } \\
39 \text { PBI APU-PPT: } \\
\text { Bank wajib } \\
\text { menatausahakan } \\
\text { dokumen-dokumen } \\
\text { dalam jangka waktu } \\
\text { sekurang-kurangnya } \\
5 \text { (lima) tahun } \\
\text { sejak Nasabah } \\
\text { menutup rekening } \\
\text { pada Bank. (Untuk } \\
\text { walk in customer, } \\
\text { selama } 5 \text { tahun } \\
\text { sejak transaksi } \\
\text { dilakukan) }\end{array}$ & $\begin{array}{l}\text { Dokumen yang ditatausahakan dalam } \\
\text { transaksi penerbitan travel cek yaitu: } \\
\text { 1. copy formulir pembelian travel cek } \\
\text { 2. copy kartu identitas pengguna jasa bank } \\
\text { 3. Formulir data nasabah khusus, untuk } \\
\text { transaksi di atas Rp. } 100.000 .000 \\
\text { 4. Formulir pendukung aplikasi transaksi } \\
\text { dan slip konfirmasi pembeli travel cek }\end{array}$ & $\begin{array}{l}\text { Petugas Back } \\
\text { Office }\end{array}$ \\
\hline 4. & $\begin{array}{l}\text { Pelaporan Transaksi } \\
\text { Keuangan } \\
\text { Mencurigakan. } \\
\text { Berdasarkan Pasal } \\
25 \text { UU Nomor } 8 \\
\text { Tahun } 2010 \\
\text { tentang } \\
\text { Pencegahan dan } \\
\text { Pemberantasan } \\
\text { Tindak Pidana } \\
\text { Pencucian Uang } \\
\text { Dilakukan oleh }\end{array}$ & $\begin{array}{l}\text { Dari data berupa SOP penerbitan dan } \\
\text { pencairan travel cek yang penulis peroleh, } \\
\text { diketahui bahwa di dalam SOP tidak } \\
\text { terdapat rincian mengenai mekanisme } \\
\text { pelaporan transaksi keuangan } \\
\text { mencurigakan. } \\
\text { Mekanisme pelaporan transaksi keuangan } \\
\text { mencurigakan diatur di dalam SOP } \\
\text { tersendiri. } \\
\text { Pada tingkat kantor pusat / cabang, } \\
\text { pimpinan kantor tersebut bertanggungjawab } \\
\text { atas pelaporan transaksi keuangan }\end{array}$ & $\begin{array}{l}\text { UPKN dan } \\
\text { Direktur } \\
\text { Kepatuhan (pada } \\
\text { tataran } \\
\text { manajemen PT) } \\
\text { dan } \\
\text { Kepala Kantor } \\
\text { Cabang untuk } \\
\text { tataran }\end{array}$ \\
\hline
\end{tabular}

Copyright (C) 2016, LITIGASI, p-ISSN: 0853-7100; e-ISSN: 2442-2274 


\begin{tabular}{|l|l|l|l|}
\hline & Unit Kerja & mencurigakan. & operasional. \\
Penerapan Prinsip & & \\
Mengenal Nasabah & & \\
(UPKN), & & \\
disampaikan & & \\
kepada PPATK & & \\
melalui Direktur & & \\
Kepatuhan dalam & & \\
jangka waktu 3 hari & & \\
kerja terhitung & & \\
sejak diketahuinya & & \\
adanya unsur & & \\
Transaksi Keuangan & & \\
Mencurigakan. & & \\
\hline 5 & Pelatihan karyawan & Pelatihan karyawan tidak termasuk dalam & Divisi yang \\
& tahapan / langkah yang harus dilakukan & bertanggungjawab \\
Bntuk \\
Berdasarkan Pasal & dalam penerbitan travel cek. & pelaksanaan \\
42 dan 43 PBI & Pengaturan tentang pelatihan karyawan & pelak \\
APU-PPT: Bank & diatur secara tersendiri. & pelatihan \\
wajib melakukan & & karyawan adalah \\
pelatihan karyawan & & Divisi Training \\
secara & (Pelatihan) yang \\
berkesinambungan & & berada di bawah \\
perihal & divisi \\
implementasi & & Pengembangan \\
peraturan & Sumber Daya \\
perundang- & & Manusia (Human \\
undangan yang & & Resources \\
terkait dengan & Development). \\
program APU dan & & \\
PPT. & & \\
\hline
\end{tabular}

Tabel 1. Penerapan Prinsip Kehati-hatian dalam Penerbitan Travel Cek (Rahel Octora, 2012 : 154-158).

b. Transaksi pencairan travel cek:

Pada prinsipnya, langkah-langkah penerapan prinsip kehati-hatian pada tahapan pencairan travel cek, sama dengan langkah-langkah yang ditempuh pada saat proses pembelian. Proses identifikasi nasabah, identifikasi transaksi mencurigakan, proses pelaporan transaksi mencurigakan dan proses penatausahaan dokumen pada 
prinsipnya sama. Berikut penulis akan memaparkan hal-hal yang bersifat khusus dalam penerapan prinsip kehati-hatian pada tahapan pencairan travel cek.

1. Tahap identifikasi dan verifikasi nasabah / pengguna jasa keuangan.

Pada tahap pencairan, nasabah wajib:

a. Mengisi dan menandatangani formulir pencairan travel cek, serta melengkapi dengan asal usul travel cek tersebut. (Untuk transaksi di atas Rp.100.000.000,- harus mengisi formulir data nasabah/walk in customer),

b. Telah menandatangani lembar travel cek yang akan dicairkan,

c. Melampirkan copy identitas diri.

Tahapan tersebut bertujuan agar pihak bank mengenali siapa pihak yang melakukan pencairan travel cek tersebut, apakah pihak pembeli travel cek, pihak ketiga yang menerima peralihan travel cek tersebut, atau pihak merchant yang menerima pembayaran barang/jasa dengan travel cek dan kemudian mencairkan travel cek tersebut. Pada proses pencairan, lembar warkat travel cek harus sudah ditandatangani. Kemudian tanda tangan tersebut diverifikasi dengan cara pihak bank meminta pembawa travel cek menandatangani sekali lagi pada kolom penguangan. Hal ini bertujuan agar orang yang mencairkan travel cek dipastikan memang orang yang berhak. Apabila travel cek berpindah tangan secara tidak sah (misalnya karena hilang / dicuri), maka pembawa tidak dapat begitu saja mencairkan travel cek nya.

2. Identifikasi transaksi keuangan mencurigakan (suspicious transaction) dan transaksi tunai dalam jumlah tertentu (cash transaction):

Copyright @ C 2016, LITIGASI, p-ISSN: 0853-7100; e-ISSN: 2442-2274 
Available online at: http://ejournal.unpas.ac.id/index.php/litigasi

Litigasi, Vol. 17(1), 2016, 3035-3074

DOI: http://dx.doi.org/10.23969/litigasi.v17i1.83

Berdasarkan penelitian yang telah dilakukan, penulis menyimpulkan adanya beberapa bentuk transaksi pencairan travel cek yang tergolong mencurigakan diantaranya:

a. Jika travel cek yang dibeli oleh satu orang, tersebar ke beberapa orang dan dicairkan oleh orang-orang yang berbeda-beda.

b. Jika penguangan travel cek dilakukan dengan cara transfer, dan rekening tujuan dimiliki oleh orang-orang yang tergolong high risk customers.

c. Jika travel cek dicairkan secara bertahap, dalam nominal-nominal kecil sehingga jika diakumulasikan memenuhi kategori transaksi yang menyimpang dari karakteristik dan profil nasabah."

3. Bank wajib melakukan pelaporan terjadinya transaksi keuangan mencurigakan sesuai ketentuan perundang-undangan.

4. Dokumen yang ditatausahakan setelah tahap pencairan travel cek adalah:

a. Lembar warkat travel cek yang dicairkan,

b. Copy identitas diri,

c. Copy formulir pencairan travel cek,

d. untuk pencairan oleh merchant, dilampirkan copy transaksi pembelian barang/jasa antara nasabah dan merchant." (Sub 3.3 sampai 3.6 Standard Operating Procedure Voucher Perjalanan).

Selain prinsip kehati-hatian, bank juga harus mentaati prinsip kepatuhan atas peraturan. Terkait dengan prinsip kepatuhan atas peraturan, maka setiap bank diwajibkan memiliki

Copyright @ C 2016, LITIGASI, p-ISSN: 0853-7100; e-ISSN: 2442-2274 
Available online at: http://ejournal.unpas.ac.id/index.php/litigasi

Litigasi, Vol. 17(1), 2016, 3035-3074

DOI: http://dx.doi.org/10.23969/litigasi.v17i1.83

unit yang diberikan tugas pokok yang fungsinya berhubungan dengan kepatuhan pada peraturan perundang-undangan. Pengemban tugas pokok fungsi tersebut dikenal dengan manajer atau direktur kepatuhan (compliance). Direktur kepatuhan adalah anggota direksi bank yang ditugaskan dan mempunyai tanggung jawab untuk memastikan bahwa langkah-langkah dalam rangka proses pengambilan keputusan oleh direksi tidak bertentangan dengan peraturan dan perundang-undangan yang berlaku, artinya seluruh kebijakan sejak awal penyusunannya diperiksa dari sisi aspek kepatuhan (Muhamad Djumhana, 2008 : 200).

Pasal 2 ayat (2) PBI No. 5/8/PBI/2003 sebagaimana telah diubah oleh PBI No.

\section{1/25/PBI/2009 mengatur:}

“ Penerapan Manajemen Risiko sebagaimana dimaksud pada ayat (1) paling kurang mencakup:

a. pengawasan aktif Dewan Komisaris dan Direksi;

b. kecukupan kebijakan, prosedur, dan penetapan limit manajemen risiko;

c. kecukupan proses identifikasi, pengukuran, pemantauan, dan pengendalian risiko, serta sistem informasi manajemen risiko; dan

d. sistem pengendalian intern yang menyeluruh."

Transaksi perbankan sehari-hari terjadi baik pada kantor pusat dan pada kantor-kantor cabang. Hal ini menunjukan bahwa tanggung jawab pelaksanaan SOP dalam setiap transaksi oleh petugas bank tidak hanya menjadi tanggung jawab petugas atau pejabat bank yang secara langsung berhubungan dengan nasabah. Bank sebagai suatu organisasi perusahaan yang sebagian besar berbentuk Perseroan Terbatas, memiliki struktur organisasi sebagaimana ditetapkan di dalam perundang-undangan (dalam hal ini UndangUndang Nomor 40 tahun 2007) tentang Perseroan Terbatas. Berdasarkan Pasal 21 UU 
Perbankan, bentuk hukum suatu Bank Umum dapat berupa : a) Perseroan Terbatas, b) Koperasi; atau c) Perusahaan Daerah.

Organ-organ yang wajib ada di dalam PT adalah Rapat Umum Pemegang Saham, Komisaris dan Direksi. Dalam UU PT dinyatakan bahwa RUPS adalah organ tertinggi di dalam suatu PT yang memiliki kewenangan yang tidak diberikan pada Komisaris dan Direksi, misalnya mengesahkan perbuatan hukum organ-organ PT sebelum PT disahkan, menyetujui perubahan anggaran dasar, menyetujui transaksi-transaksi berkenaan dengan saham,penambahan dan pengurangan modal,persetujuan dan pengesahan laporan keuangan,mengangkat,memutuskan besar gaji, memutuskan pemberhentian Direksi dan Komisaris, menyetujui rancangan penggabungan, peleburan, pengambilalihan dan atau pemisahan PT, pembubaran PT dan wewenang lain sebagaimana ditentukan di dalam UU PT. Dalam rangka kegiatan operasional perbankan, setiap organ tersebut berperan:

"Dewan Komisaris aktif terlibat dalam penetapan kerangka kerja pengelolaan risiko secara keseluruhan. Direksi melaksanakan amanat Dewan Komisaris dengan menyusun strategi dan pedoman pelaksanaan serta berperan aktif dalam pengelolaan risiko (Fadil Zumhana, 2011 : 15)."

Kewajiban Komisaris dan Direksi dalam hal pengelolaan risiko diatur secara konkrit sebagai berikut:

Pasal 6 PBI No. 5/8/PBI/2003:

"Wewenang dan tanggung jawab sebagaimana dimaksud dalam Pasal 5 bagi Dewan Komisaris sekurang-kurangnya:

a. menyetujui dan mengevaluasi kebijakan Manajemen Risiko;

Copyright @ C 2016, LITIGASI, p-ISSN: 0853-7100; e-ISSN: 2442-2274 
b. mengevaluasi pertanggungjawaban Direksi atas pelaksanaan kebijakan Manajemen Risiko sebagaimana dimaksud dalam huruf a;

c. mengevaluasi dan memutuskan permohonan Direksi yang berkaitan dengan transaksi yang memerlukan persetujuan dewan Komisaris."

Pasal 7 ayat (1) PBI No. 5/8/PBI/2003:

“Wewenang dan tanggung jawab sebagaimana dimaksud dalam Pasal 5 bagi Direksi sekurang-kurangnya:

a. menyusun kebijakan dan strategi Manajemen Risiko secara tertulis dan komprehensif;

b. bertanggung jawab atas pelaksanaan kebijakan Manajemen Risiko dan eksposur Risiko yang diambil oleh Bank secara keseluruhan;

c. mengevaluasi dan memutuskan transaksi yang memerlukan persetujuan Direksi;

d. mengembangkan budaya Manajemen Risiko pada seluruh jenjang organisasi;

e. memastikan peningkatan kompetensi sumberdaya manusia yang terkait dengan Manajemen Risiko;

f. memastikan bahwa fungsi Manajemen Risiko telah beroperasi secara independen;

g. melaksanakan kaji ulang secara berkala untuk memastikan:

1. keakuratan metodologi penilaian Risiko;

2. kecukupan implementasi sistem informasi manajemen; dan

3. ketepatan kebijakan, prosedur dan penetapan limit Risiko."

Berdasarkan Pasal 4 PBI Nomor 11/28/ PBI / 2009, Anggota Direksi diberikan tanggung jawab untuk melakukan pengawasan aktif.

"Pengawasan aktif Direksi Bank paling kurang mencakup:

a. memastikan Bank memiliki kebijakan dan prosedur program APU (Anti Pencucian Uang) dan PPT (Pencegahan Pendanaan Terorisme);

b. mengusulkan kebijakan dan prosedur tertulis program APU dan PPT kepada Dewan Komisaris;

c. memastikan penerapan program APU dan PPT dilaksanakan sesuai dengan kebijakan dan prosedur tertulis yang telah ditetapkan;

d. memastikan bahwa satuan kerja yang melaksanakan kebijakan dan prosedur program APU dan PPT terpisah dari satuan kerja yang mengawasi penerapannya;

Copyright (C) 2016, LITIGASI, p-ISSN: 0853-7100; e-ISSN: 2442-2274 
Available online at: http://ejournal.unpas.ac.id/index.php/litigasi

Litigasi, Vol. 17(1), 2016, 3035-3074

DOI: http://dx.doi.org/10.23969/litigasi.v17i1.83

e. membentuk unit kerja khusus yang melaksanakan program APU dan PPT dan/atau menunjuk pejabat yang bertanggungjawab terhadap Program APU dan PPT di Kantor Pusat;

f. pengawasan atas kepatuhan satuan kerja dalam menerapkan program APU dan PPT;

g. memastikan bahwa kantor cabang dan kantor cabang pembantu Bank memiliki pegawai yang menjalankan fungsi unit kerja khusus atau pejabat yang melaksanakan program APU dan PPT;

h. memastikan bahwa kebijakan dan prosedur tertulis mengenai program APU dan PPT sejalan dengan perubahan dan pengembangan produk, jasa, dan teknologi Bank serta sesuai dengan perkembangan modus pencucian uang atau pendanaan terorisme; dan

i. memastikan bahwa seluruh pegawai, khususnya pegawai dari unit kerja terkait dan pegawai baru, telah mengikuti pelatihan yang berkaitan dengan program APU dan PPT secara berkala."

2. Potensi terjadi risiko yang cukup besar terjadi pada proses peralihan travel cek. Travel cek yang diterbitkan dalam bentuk blanko, dapat beralih dari pembeli yang pertama kepada orang lain di luar kendali dan pengawasan bank.

Surat berharga pada umumnya diterbitkan dengan klausula atas tunjuk, atau atas pengganti. Demikian pula dengan Travel Cek, dapat diterbitkan atas tunjuk atau atas pengganti atau tidak atas pengganti. Perbedaannya adalah: (Abdulkadir Muhammad, $1984: 170)$.

a. Jika diterbitkan atas tunjuk, setiap orang dapat menguangkannya dengan menunjukkan dan menyerahkan surat cek tersebut. Bahayanya ialah apabila lepas dari penguasaan yang berhak, surat cek tersebut dapat diuangkan oleh orang yang tidak berhak tanpa kesulitan apapun.

b. Travel cek yang diterbitkan atas pengganti, lebih aman sebab hanya dapat diuangkan oleh orang yang berhak menurut hukum cek, yaitu orang yang memperolehnya dengan endosemen. Endosemen adalah lembaga pemindahan

Copyright @ C 2016, LITIGASI, p-ISSN: 0853-7100; e-ISSN: 2442-2274 
Available online at: http://ejournal.unpas.ac.id/index.php/litigasi

Litigasi, Vol. 17(1), 2016, 3035-3074

DOI: http://dx.doi.org/10.23969/litigasi.v17i1.83

hak milik atas tagihan pada surat berharga yang berklausula atas pengganti (aan order).

c. Jika diterbitkan tidak atas pengganti, lebih aman lagi karena yang menguangkan surat cek itu hanyalah pemilik yang berhak itu sendiri.

Dalam praktik, yang paling banyak dijumpai adalah travel cek dalam bentuk atas tunjuk. Dengan demikian, travel cek dapat beralih kepada siapapun, dan proses peralihan itu dapat saja didasari oleh suatu kausa yang tidak halal, misalnya salah satu pihak memberikan travel cek kepada pihak lain sebagai bentuk suap atau gratifikasi (dalam kasus ini motivasi dari pemberian travel cek sebagai sarana suap atau gratifikasi menyebabkan lahirnya perikatan pokok dengan kausa yang tidak halal).

Copyright (C) 2016, LITIGASI, p-ISSN: 0853-7100; e-ISSN: 2442-2274 
Available online at: http://ejournal.unpas.ac.id/index.php/litigasi

Litigasi, Vol. 17(1), 2016, 3035-3074

DOI: http://dx.doi.org/10.23969/litigasi.v17i1.83

\section{SIMPULAN DAN SARAN}

A. Simpulan

1. Transaksi penerbitan dan pencairan traveller's cheque dapat dikategorikan sebagai transaksi ilegal yang menimbulkan risiko bagi bank dalam kondisi sebagai berikut:

a. Terjadi penyimpangan yang dilakukan terhadap Standard Operational Procedure transaksi, dan dilakukan secara sengaja (diketahui dan disadari) baik oleh oknum pegawai bank, dan/atau pejabat bank. Hal ini memenuhi unsur delik yang dirumuskan dalam Pasal 49 ayat (2) butir b UndangUndang Nomor 7 tahun 1992 sebagaimana diubah dengan UndangUndang Nomor 10 tahun 1998 tentang Perbankan.

b. Terjadi tindakan melawan hukum dalam proses peralihan travel cek oleh pihak/pemegang yang beritikad buruk, misalnya travel cek dialihkan kepada pejabat negara sebagai sarana suap, gratifikasi, atau travel cek digunakan sebagai media pencucian uang. Dalam hal terjadi kondisi demikian, bank perlu berhati-hati dan mengidentifikasi potensi transaksi ilegal dalam proses pencairan travel cek.

2. Kepatuhan terhadap peraturan perundang-undangan merupakan bentuk perwujudan prudential banking dan manajemen risiko. Prudential banking dan manajemen risiko merupakan sesuatu yang wajib dilaksanakan oleh bank, mengingat ketidakpatuhan terhadap peraturan perundang-undangan berarti telah mengabaikan aturan dan prinsip kehati-hatian. Ketidakpatuhan terhadap

Copyright @ 9 2016, LITIGASI, p-ISSN: 0853-7100; e-ISSN: 2442-2274 
Available online at: http://ejournal.unpas.ac.id/index.php/litigasi

Litigasi, Vol. 17(1), 2016, 3035-3074

DOI: http://dx.doi.org/10.23969/litigasi.v17i1.83

peraturan perundang-undangan dapat dikualifikasikan sebagai pelanggaran dan atau kejahatan yang lebih jauh berdampak pada sanksi. Terkait transaksi penerbitan dan pencairan Traveller's Cheque yang bersifat ilegal, apabila telah terjadi transaksi ilegal karena adanya pelanggaran SOP dengan sepengetahuan dan persetujuan pejabat bank yang bertugas untuk mengawasi transaksi oleh pegawai bank tugas secara sengaja, maka telah memenuhi unsur sebagaimana dimaksud dalam Pasal 49 ayat (2) butir b UU Perbankan. Maka bagi pejabat bank yang bersangkutan dikenakan sanksi pidana, sedangkan di sisi lain Bank terkait dapat dikenakan sanksi administratif berdasarkan peraturan perundangundangan.

3. Untuk mencegah timbulnya tindak pidana di bidang perbankan, sistem manajemen risiko dalam transaksi penerbitan dan pencairan traveller's cheque seharusnya diterapkan sebagai berikut:

a. Tahapan KYC dan CDD principles diterapkan dalam SOP transaksi terutama pada tahapan "identifikasi transaksi mencurigakan".

b. Pengawasan aktif Direksi dan penegasan fungsi compliance dalam struktur organisasi bank.

Copyright @ C 2016, LITIGASI, p-ISSN: 0853-7100; e-ISSN: 2442-2274 
Available online at: http://ejournal.unpas.ac.id/index.php/litigasi

Litigasi, Vol. 17(1), 2016, 3035-3074

DOI: http://dx.doi.org/10.23969/litigasi.v17i1.83

\section{B. Saran}

1. Untuk Bank Indonesia agar melakukan peninjauan dan atau revisi terhadap ketentuan yang terkait dengan transaksi penerbitan dan pencairan travel cek, termasuk mengakomodir sanksi bagi bank yang tidak melakukan ketentuanketentuan dalam SOP.

2. Agar bank-bank yang melakukan aktivitas penerbitan dan pencairan travel cek membenahi SOP internal agar selaras dengan prinsip-prinsip manajemen risiko guna meminimalisir kerugian yang dihadapi, mengingat transaksi ini rentan terhadap tindak pidana.

3. Dengan adanya lembaga OJK, maka pengawasan terhadap kegiatan perbankan lebih diintensifkan dan dilakukan secara integratif agar sesuai dengan prinsipprinsip kehati-hatian dan manajemen risiko.

Copyright (C) 2016, LITIGASI, p-ISSN: 0853-7100; e-ISSN: 2442-2274 
Available online at: http://ejournal.unpas.ac.id/index.php/litigasi

Litigasi, Vol. 17(1), 2016, 3035-3074

DOI: http://dx.doi.org/10.23969/litigasi.v17i1.83

\section{DAFTAR PUSTAKA}

\section{BUKU}

Adam, 1976, The Theory of Moral Sentiments, Indianapolis: Oxford University Press.

A.H. Semendawai, 2005, Tanggung Jawab Pidana Korporasi Dalam RUU KUHP, Jakarta: Lembaga Studi Advokasi Masyarakat.

Abdulkadir Muhammad, 1984, Hukum Dagang tentang Surat-surat Berharga, Bandung: Alumni.

Ahmad Fuad, 2011, Penegakan Hukum dan Upaya Pencegahan terhadap Kejahatan Perbankan, Bandung: Sekolah Tinggi Hukum Bandung.

Andy Hamzah, 1985, Pengantar Hukum Pidana Indonesia, Jakarta: Ghalia Indonesia.

Barda Nawawi Arief, 1990, Pelengkap Bahan Kuliah Hukum Pidana I, Cetakan Ke I, Semarang: Fakultas Hukum Universitas Diponegoro.

Emmy Panggaribuan, 1979, Hukum Dagang Surat-Surat Berharga, Yogyakarta: Seksi Hukum Dagang FH - UGM.

Fajrimei A. Gofar, 2005, Asas Legalitas dalam Rancangan KUHP, Jakarta: Lembaga Studi Advokasi Masyarakat.

Jan Remelink, 2003, Hukum Pidana, Komentar atas Pasal-Pasal Terpenting dari Kitab Undang-Undang Hukum Pidana Belanda dan Padanannya dalam Kitab UndangUndang Hukum Pidana Indonesia, Jakarta: Gramedia Pustaka Utama.

Kasmir, 1998, Bank dan Lembaga Keuangan Lainnya (Edisi Baru), Jakarta: Raja Grafindo Persada.

Mahrus Ali, 2011, Dasar-Dasar Hukum Pidana, Jakarta: Sinar Grafika.

Marjono Reksodiputro, 1994, Kemajuan Pembangunan Ekonomi dan Kejahatan, Kumpulan Karangan Buku Kesatu, Jakarta: Pusat Pelayanan Keadilan dan Pengabdian Hukum.

Moch Anwar dan Mardjono Reksodiputro, 1986, Tindak Pidana Di Bidang Perbankan, Bandung: Alumni. 
Moch. Chidir Ali, et.al, 1994, Surat Berharga Cek, Wesel dan Giro Bilyet, Bandung: Mandar Maju.

Moeljatno, 2002, Asas-asas Hukum Pidana, Jakarta: Rineka Cipta.

Muhammad Djumhana, 2008, Asas-asas Hukum Perbankan Indonesia, Bandung: Citra Aditya Bakti.

Muladi dan Dwidja Priyatno, 2010, Pertanggungjawaban Pidana Korporasi, Jakarta: Prenada Media Group.

Munir Fuady, 2005, Pengantar Hukum Bisnis, Menata Bisnis Modern di Era Global, Bandung: Citra Aditya Bakti.

PAF. Lamintang, 1996, Dasar-dasar Hukum Pidana Indonesia, Bandung: Citra Aditya Bakti.

R. Edward Freeman, 1985, Manajemen Strategik, Pendekatan Terhadap Pihak-Pihak Berkepentingan, Jakarta: Pustaka Binaman Presindo.

RA. Supriyono, 1990, Manajemen Strategi dan Kebijaksanaan Bisnis, Yogyakarta: BPFE.

Satjipto Rahardjo, 2000, Ilmu Hukum, Bandung: Citra Aditya Bakti.

Serge Lanskoy, 2000, Legal Nature of Electronic Money, Banque De France: Bulletin Digest, N.73.

Sonny Keraf, 1996, Pasar Bebas Keadilan dan Peran Pemerintah, Yogyakarta: Kanisius.

Sudarto, 2007, Hukum dan Hukum Pidana, Bandung: Alumni.

Sudarto, 1991, Hukum Pidana, Purwokerto: Fakultas Hukum Unsoed.

Sutan Remi Sjahdeini, 2006, Pertanggungjawaban Pidana Korporasi, Jakarta: Grafiti Pers.

Tim Pengaturan dan Perizinan Sistem Pembayaran, 2004, Kajian Konstruksi Hukum Pembayaran Giral di Indonesia, Jakarta: Biro Pengembangan Sistem Pembayaran Nasional Bank Indonesia.

Wawan Purwanto, 2011, Risiko Manajemen Perbankan, Jakarta: CMB Press. 
Wirjono Prodjodikoro, 1980, Hukum Wesel, Cek, dan Aksep di Indonesia, Bandung: Sumur Bandung.

. 1989. Asas-asas Hukum Pidana di Indonesia. Bandung: Eresco.

\section{JURNAL}

Yunus Husein, 2001, Penerapan Prinsip Mengenal Nasabah oleh Bank dalam Rangka Penanggulangan Kejahatan Money Launderying, Jurnal Hukum Bisnis Volume 16.

TESIS

Rahel Octora, 2012, Pertanggungjawaban Pidana Bank Atas Kejahatan Penyalahgunaan Traveller's Cheque Dikaitkan dengan Kewajiban Penerapan Prinsip Kehatihatian, Bandung: Tesis Universitas Katholik Parahyangan.

\section{MAKALAH}

Fadil Zumhanna, 2011, Kredit Macet dan Strategi Pencegahan Terjadinya Tindak Pidana Korupsi.

\section{WEBSITE}

Bismar Nasution. 2009. Kejahatan Korporasi dan Pertanggungjawabannya. http://bismar.wordpress.com/2009/12/23/kejahatan-korporasi/

Ivan Lanin. 2012. Sebelas Prinsip Manajemen Risiko, http://iknow.apbgroup.com/sebelas-prinsip-manajemen-risiko-menurut-iso-31000/Dipublikasi pada 11 Oktober 2012.

\section{PERATURAN PERUNDANGAN}

Undang-Undang Nomor 7 Tahun 1992 tentang Perbankan

Undang-Undang Nomor 10 Tahun 1998 tentang Perubahan Atas Undang-Undang Nomor 7 Tahun 1992 tentang Perbankan

Peraturan Bank Indonesia 5/ 21 /PBI/2003 tentang Perubahan Kedua atas PBI No. 3/10/ PBI/2001 tentang Penerapan Prinsip Mengenal Nasabah (Know Your Customer Principles). 
Available online at: http://ejournal.unpas.ac.id/index.php/litigasi

Litigasi, Vol. 17(1), 2016, 3035-3074

DOI: http://dx.doi.org/10.23969/litigasi.v17i1.83

Peraturan Bank Indonesia Nomor 11/28/ PBI / 2009 tentang Penerapan Program Anti Pencucian Uang dan Pencegahan Pendanaan Terorisme Bagi Bank Umum.

\section{LAIN-LAIN}

Pedoman Standard Penerapan Prinsip Mengenal Nasabah, Bank Indonesia, Bab II Sub. A Standard Operating Procedure Voucher Perjalanan. 